\title{
Comparison of the Troponin T and Troponin I ELISA Tests, as Measured by Microplate Immunoassay Techniques, in Diagnosing Acute Myocardial Infarction
}

\author{
Karri Penttilä ${ }^{1}$, Ilkka Penttilä ${ }^{1}$, Rosemary Bonnell ${ }^{3}$, Paul Kerth $^{3}$, Heli Koukkunen ${ }^{2}$, Tapio Rantanen $^{1}$ and \\ Gregory Svanas ${ }^{3}$ \\ ${ }^{1}$ Department of Clinical Chemistry, Kuopio University Hospital, Kuopio, Finland \\ 2 Department of Medicine, Kuopio University Hospital, Kuopio, Finland \\ ${ }^{3}$ Spectral Diagnostics Inc., Toronto, Canada
}

Summary: We describe an improved procedure using a standard microplate immunoassay reader to measure the concentration of troponin $T$ in human serum. We also describe an immunoassay for troponin I in serum. Only $160 \mu 1$ of serum are needed for a single analysis of each troponin. For comparison, creatine kinase MB mass analysis in serum was performed with a commercial luminometric method. From 95 apparently healthy people the following values were obtained: creatine kinase MB mass $2.6 \pm 1.2 \mu \mathrm{g} / \mathrm{l}$, troponin $\mathrm{T} 0.027 \pm 0.025 \mu \mathrm{g} / \mathrm{l}$ and troponin I $0.03 \pm 0.031 \mu \mathrm{g} / 1$.

We compared the results of troponin $\mathrm{T}$ and troponin I methods with each other, as well as with those of creatine kinase MB mass measured in 48 patients with verified acute myocardial infarction and in 60 control patients with non-cardiac chest pain. The correlation between troponin $T$ and troponin I values was 0.91 for the total material and 0.94 for 48 patients with acute myocardial infarction. Troponin I showed better earlier sensitivity than troponin T $(p=0.043)$. In nine patients in the control group, creatine kinase MB mass exceeded the reference limit of $5.0 \mu \mathrm{g} / \mathrm{l}$, while in two patients the cut-off limit of $10.0 \mu \mathrm{g} / \mathrm{l}$ was also surpassed, pointing to non-specificity.

In the group of infarct patients, the highest serum creatinine value was $193 \mu \mathrm{mol} / \mathrm{l}$, whereas in the control group it was $406 \mu \mathrm{mol} / \mathrm{l}$. The sera of patients with impaired renal function without any cardiac failure showed no increase in troponin $\mathrm{T}$ and troponin I values.

In conclusion, serum creatine kinase MB mass and troponin I seem to confirm an acute myocardial infarction more rapidly than does troponin $\mathrm{T}$; troponin I has the highest cardiac specificity.

\section{Introduction}

Troponin $\mathrm{T}$, troponin $\mathrm{I}$ and troponin $\mathrm{C}$ belong to the family of troponins in muscle tissues $(1,2)$. Troponins are located in the thin filament of the myocyte. Troponin $\mathrm{T}$ has the highest relative molecular mass $\left(M_{\mathrm{r}}=37000\right)$, while the relative molecular mass of troponin $\mathrm{I}$ is $M_{\mathrm{r}}$ $=24000$ and that of troponin $\mathrm{C}$ is $M_{\mathrm{r}}=20000$ (2). The function of troponin $\mathrm{T}$ is to bind the other troponins to the tropomyosin filament of the myocyte, while troponin I inhibits actomyosin ATPase, and troponin $\mathrm{C}$ binds $\mathrm{Ca}^{2+}$ ions (3). When cardiac muscle fibres are damaged they release first the cytosolic and subsequently the complexed troponins into the circulation $(4,5)$. In cardiac muscle this release depends on the recanalization of the damaged muscle area, which is much more advanced in cases of early reperfusion than in a stabile occlusion $(4,5)$. This provides a means of following the progress of the myocardial infarction as a function of time (4-6).
Troponin $\mathrm{T}$ and troponin I are proteins found in both myocardial and in skeletal muscles. Analysis of the amino acid contents and the structure of troponin $T$ and troponin $I(7,8)$ has verified that there are such marked structural differences between myocardial and skeletal proteins in adults that distinct and highly specific antibodies against myocardial troponin $\mathrm{T}$ and troponin I can be produced (4, 5, 7-9). Using two selected monoclonal antibodies, Katus and coworkers (10) developed a new, highly specific enzyme-linked immunosorbent assay (ELISA) method for the measurement of serum cardiac troponin $T$, and showed that skeletal troponin $\mathrm{T}$ has minimal crossreactivity with this antibody. Likewise, Larue and coworkers (5) developed an immunoenzymometric assay using two very specific antibodies for measuring troponin $I$ in human serum. Many recent studies have shown that 
the troponin $\mathrm{T}$ and troponin I methods are very useful in the diagnosis of acute myocardial infarction and for estimating the fate of the patients with unstable angina pectoris $(3,5,6,10-13)$.

In this article we describe an improved modification of our ELISA procedure (14) for measuring troponin $T$ using a standard microtitre plate immunoassay reader (15) and an ELISA procedure for troponin I. For comparison, creatine kinase $\mathrm{MB}^{1}$ ) mass was measured in serum.

The main purpose of the present investigation was to study the usefulness of the immunochemical methods for troponin T and I, as well as for creatine kinase MB mass, to distinguish patients with definite acute myocardial infarction from those with non-cardiac chest pain. This formed part of a larger study of patients coming to the hospital with chest pain. For this purpose we tried to reduce the between-series variation of our troponin $\mathrm{T}$ procedure (14). Secondly we studied the use of troponin $I$ in the diagnosis of acute myocardial infarction using a standard microtitre immunoassay technique. And thirdly we compared the usefulness of serum troponin $\mathrm{T}$, troponin I and serum creatine kinase $\mathrm{MB}$ mass values in serum for monitoring patients after onset of chest pain.

\section{Materials and Methods}

Samples

For the present study, part of the samples from patients of the emergency department of the Kuopio University Hospital were taken for ordinary serum enzyme assays (creatine kinase, creatine kinase isoenzyme $\mathrm{MB}$ and lactate dehydrogenase isoenzyme 1$)^{1}$ ) and stored at $-70^{\circ} \mathrm{C}$ until analysed for troponin $\mathrm{T}$, troponin I and creatine kinase MB mass. Venous blood samples for enzyme determinations were collected with minimal stasis and centrifuged within $60 \mathrm{~min}$ to obtain serum for analyses. Haemolysed samples were replaced by new samples. For measuring the variations within-series and between-series, two serum pools were made, divided into $1.0 \mathrm{ml}$ portions and stored at $-70^{\circ} \mathrm{C}$ until analysed.

Forty-eight consecutive patients with acute myocardial infarction (16) and 60 patients with non-cardiac chest pain were enrolled at the emergency care department for the study. The patients were classified into diagnostic categories using modified FINMONICA criteria, which are based on symptoms, electrocardiographic findings and traditional enzymes. The clinical data of the patients is presented in detail in table 1.

In addition, the creatine kinase MB mass, troponin $\mathrm{T}$ and troponin I values were measured in the sera of 95 apparently healthy people (students, laboratory personnel and firemen, assessing as healthy by determination of blood haemoglobin and packed cell volume and differential blood cell count).

\section{Methods and reagents}

Serum troponin $\mathrm{T}$ was previously measured by using the Troponin$\mathrm{T}$ kit of Boehringer Mannheim (Mannheim, Germany) for the ES-

\footnotetext{
1) Enzymes:

Creatine kinase (EC 2.7.3.2)

Creatine kinase isoenzyme MB

Lactate dehydrogenase (1.1.1.27) isoenzyme 1
}

series of analysers. For the determination of troponin $\mathrm{T}$ as a microtitre plate immunoassay method, unmodified reagents for the Enzymun-Test ${ }^{\circledR}$ (Cat. No. 1556428) produced by Boehringer Mannheim were used (14). Instead of the original tubes, the reaction was performed in the $250 \mu \mathrm{l}$ wells of a microtitre plate after coating the wells with streptavidine. Commercial microtitre plates coated with streptavidine (Labsystems Co., Helsinki, Finland) were found to be useful. Coated microtitre plates were stored at $+4{ }^{\circ} \mathrm{C}$ until used. Otherwise, the method was performed in a similar way to that presented earlier (14) with minor modifications (15). Standard, control and serum ( $30 \mu \mathrm{l}$ each) were dispensed into the wells of the plate with a manual Proline 5-50 pipette of Biohit Co. (Helsinki, Finland). The tip of the pipette was changed after each operation. A mixture of antibodies to troponin $\mathrm{T}(200 \mu \mathrm{l})$ was then added with a multitip automated pipette (Proline Electronic 250, Biohit Co.), and the plate was incubated for $30 \mathrm{~min}$ at $25^{\circ} \mathrm{C}$ in a shaker (Wellwarm 1 Shaker, Denley, England) and washed twice with the washing solution using a Multiwash instrument (Labsystems Co.). Then the substrates (di-ammonium 2,2'-azino-bis[3-ethylbenzothiazoline-6-sulphonate] and $\mathrm{H}_{2} \mathrm{O}_{2}$ ) were added and the microtitre plate was incubated on a Multiscan MCC $/ 340$ reader (Labsystems Co.) for $10 \mathrm{~min}$, after which the intensity of the colour in the wells was read at $405 \mathrm{~nm}$. The concentrations of troponin $T$ were then obtained from a standard curve prepared by the Genesis ${ }^{\circledR}$ program of Labsystems Co. using a microcomputer connected on-line to the Multiscan reader.

The standard curve for troponin $\mathrm{T}$ was constructed as follows: Standards were $0.0,0.9,2.4,5.2,10.7$ and $14.5 \mu \mathrm{g} / \mathrm{l}$. The concentrations in the controls purchased with the kit were low $(0.19$ $\pm 0.06 \mu \mathrm{g} / \mathrm{l})$ and high $(5.45 \pm 0.82 \mu \mathrm{g} / \mathrm{l})$.

The concentration of troponin I in serum (troponin I) was measured using the reagents from the Spectral Co. (Toronto, Canada) as recommended by the manufacturer as follows: Microtitre plates of Biohit Co. (12 PCS 8-well strips/plate) were coated with goat antitroponin I antibody at $4.0 \mathrm{mg} / 1 \mathrm{in} 0.1 \mathrm{mg} / \mathrm{l}$ sodium citrate buffer, $\mathrm{pH} 4.0$ overnight. After washing the wells four times with $0.1 \mathrm{~mol} / 1$ phosphate buffer, $\mathrm{pH} 6.8$ containing $0.15 \mathrm{~mol} / \mathrm{l}$ of $\mathrm{NaCl}$, the wells were incubated with $250 \mu \mathrm{l}$ of blocking buffer (digested casein, 10 $\mathrm{g} / 1$ in $0.3 \mathrm{~mol} / 1 \mathrm{NaCl}$ ) for $60 \mathrm{~min}$, washed four times with $0.1 \mathrm{~mol} / 1$ phosphate $/ 0.15 \mathrm{~mol} / 1 \mathrm{NaCl}$ buffer, $\mathrm{pH} 7.0$ containing $250 \mu \mathrm{l} / 1$ of Tween-20, and once with $0.1 \mathrm{~mol} / 1$ phosphate $/ 0.15 \mathrm{~mol} / 1 \mathrm{NaCl}$ buffer and then dried. Standard, control or serum were added to the appropriate well in duplicate. Then $50 \mu 1$ of incubation buffer $(50 \mu \mathrm{l}$ each) containing detector antibodies (monoclonal antibodies Mab 81-7 and Mab 21-14 at $5 \mathrm{mg} / \mathrm{l}$ in EDTA-Tris-casein, $\mathrm{NaCl}$ and Tween-20 buffer, $\mathrm{pH} 6.0$ ) were added to each well and the plate incubated at $25^{\circ} \mathrm{C}$ for $45 \mathrm{~min}$ on a shaker $\left(200 \mathrm{~min}^{-1}\right)$. After washing four times with phosphate/ $\mathrm{NaCl}$ buffer with Tween-20 and once with phosphate/ $\mathrm{NaCl}$ buffer as before, the wells were dried. Instead of the $o$-phenylenediamine dihydrochloride substrate used by

Tab. 1 The basic clinical data of the patients participating in the present study, expressed as mean values (range).

\begin{tabular}{lll}
\hline & $\begin{array}{l}\text { Infarction } \\
\text { group }\end{array}$ & $\begin{array}{l}\text { Control } \\
\text { group }\end{array}$ \\
\hline $\begin{array}{l}\text { Number of patients } \\
\quad \text { Males }\end{array}$ & 48 & 60 \\
$\quad 32$ & 32 \\
Meamales & 16 & 28 \\
Mean body weight, kg & $66(45-91)$ & $63(20-89)$ \\
$\begin{array}{l}\text { Mean time from onset of } \\
\text { chest pain to hospitalization, } \mathrm{h}\end{array}$ & $79(39-130)$ & $70(49-117)$ \\
$\begin{array}{l}\text { Number of deaths during } \\
\text { hospitalization }\end{array}$ & 1 & $6.2(1.1-55)$ \\
$\begin{array}{l}\text { Number of patients with } \\
\text { thrombolytic treatment }\end{array}$ & 24 & 0 \\
\hline
\end{tabular}


Tab. 2 The schemes for the determination of serum troponin $T$ and troponin I using the microplate immunoassays. ABTS ${ }^{(}=$

substrate di-ammonium 2,2'-azino-bis(3-ethylbenzothiazoline-6sulphonate).

\begin{tabular}{|c|c|c|}
\hline Action & & Troponin I \\
\hline Coating of the microtitre plate wells & Streptavidin & Anti-troponin I \\
\hline $\begin{array}{l}\text { Sample/Standard } \\
\text { Anti-troponin T antibody, biotinylated and anti-troponin T antibody, enzyme conjugated } \\
\text { Anti-troponin I, enzyme conjugated } \\
\downarrow\end{array}$ & $\begin{array}{l}30 \mu l \\
200 \mu l\end{array}$ & $50 \mu l$ \\
\hline The microtitre plates were incubated at $25^{\circ} \mathrm{C}$ for & $30 \mathrm{~min}$ & $45 \mathrm{~min}$ \\
\hline Washings of the wells with washing solutions & two times & four times \\
\hline $\begin{array}{l}\text { Addition of reagents } \mathrm{ABTS}^{\circledR} \text { and } \mathrm{H}_{2} \mathrm{O}_{2} \\
\downarrow \\
\text { Incubation of the mixture at } 25^{\circ} \mathrm{C} \text { for } \\
\downarrow \\
\text { Measurement of the colour directly from the microtitre plate wells at } 405 \mathrm{~nm} \text {. }\end{array}$ & $\begin{array}{l}200 \mu l \\
10 \mathrm{~min}\end{array}$ & $\begin{array}{l}120 \mu \mathrm{l} \\
10 \mathrm{~min}\end{array}$ \\
\hline
\end{tabular}

Results obtained from the standard curves made by the Genesis ${ }^{\circledR}$ program

Spectral Co., $120 \mu \mathrm{l}$ of the substrates (di-ammonium 2,2'-azinobis[3-ethylbenzothiazoline-6-sulphonate, Sigma Co.] and $\mathrm{H}_{2} \mathrm{O}_{2}$ ) were added and the microtitre plate was incubated on a Multiscan $\mathrm{MCC} / 340$ reader (Labsystems $\mathrm{Co}$.) for $10 \mathrm{~min}$ at room temperature in the dark, after which the intensity of the colour in the wells was read at $405 \mathrm{~nm}$. The concentrations of troponin I were then obtained from a standard curve prepared by the Genesis ${ }^{\circledR}$ program of Labsystems Co. using a microcomputer connected on-line to the Multiscan reader.

The standard curve for troponin I was constructed by using the following standards from the manufacturer: $0.0,0.1,0.2,0.39$, $0.78,1.56,3.125,6.25,12.5$ and $25 \mu \mathrm{g} / \mathrm{l}$. The controls purchased from the manufacturer were low $(0.39 \pm 0.09 \mu \mathrm{g} / \mathrm{l})$ and high $(7.45$ $\pm 0.92 \mu \mathrm{g} / 1)$.

Serum creatine kinase (EC 2.7.3.2) was measured with a commercial assay from Boehringer Mannheim according to the ECCLS recommendation (17), using a Hitachi 717 analyser (Tokyo, Japan). The activity of the creatine kinase $B$ isoenzyme was measured after inhibiting the $M$-subunit with anti-creatine kinase $M$ antibody (Boehringer Mannheim), and expressed as the value of creatine kinase $\mathrm{MB}$ by doubling the measured creatine kinase $\mathrm{B}$ value. The activity of lactate dehydrogenase (EC 1.1.1.27) and its isoenzyme 1 after inhibition of the M-containing isoenzymes with urea and guanidine at $\mathrm{pH} 10$ was measured according to the lactate dehydrogenase method of Boehringer Mannheim using a Hitachi 717 analyser in accordance with the Scandinavian Recommendation (18).

The mass concentration of creatine kinase MB in serum was measured using a monoclonal anti-creatine kinase $\mathrm{MB}$ antibody bound to latex microparticles and a second polyclonal anti-creatine kinase-MM antibody coupled with alkaline phosphatase (19) by a commercial IMx ${ }^{\circledR}$ creatine kinase MB assay (Abbott Laboratories, Abbott Park, Ill., USA).

The creatinine concentration in serum was measured with an automated kinetic alkaline picrate method using a Hitachi 717 Analyser. The reference values of serum creatinine for men are 60-105 and for women $50-90 \mu \mathrm{mol} / \mathrm{l}$.

\section{Statistics}

Student's t-test and a non-parametric test (Wilcoxon's signed rank test) were used to compare results between methods and patient groups using the StatView 4.0 software package (Abacus Concepts Inc., Berkeley, Ca., USA). The correlations between the method groups were performed using a two-by-two contingency tables test with SPSS/PC + software package version 5.0.1 (20).

\section{Results}

The patients with chest pain were classified into diagnosis categories using FINMONICA criteria based on the recommendation of WHO (16). All 48 patients with acute myocardial infarction had typical symptoms, diagnostic electrocardiographic findings and elevated creatine kinase, creatine kinase isoenzyme MB and lactate dehydrogenase 1 activity values in serum. In contrast, the control group consisted of 60 patients, who had no infarction, no abnormal electrocardiographic findings and ordinary enzyme activity values; although they had chest pain this was apparently not of cardiac origin. The creatine kinase MB mass, troponin T and troponin I values in the serum of these patients were then measured to evaluate the usefulness of creatine kinase MB mass and troponins in the diagnosis of acute myocardial infarction.

\section{Evaluation of the microtitre plate ELISA methods for the determination of troponin $T$ and troponin I}

Initially, the linearity of the Multiscan microtitre plate reader to be used in the measurements was studied. By using different dilutions of potassium dichromate, the instrument was found to be linear at $405 \mathrm{~nm}$ up to $\mathrm{A}_{405}=2.400$ using different dilutions of dichromate. At absorbances of 0.3 and 1.5, the readings from the 250 $\mu \mathrm{l}$ wells containing $200 \mu \mathrm{l}$ of the colour red solution revealed variations below $1.0 \%$.

Using increasing concentrations of troponin $T$, it was found that the streptavidine coating of every $250 \mu \mathrm{l}$ well should be able to bind at least $2 \mathrm{ng}$ of biotin for proper functioning of the assay. The incubation times and temperature were also studied, and it was shown that assays can be performed at $25^{\circ} \mathrm{C}$ and that $30 \mathrm{~min}$ for the antigen- 
antibody reaction and $10 \mathrm{~min}$ for the colour reaction were optimal. The microtitre plate must be washed mechanically, not manually, in order to obtain consistent results.

The microtitre plates for troponin I measurement were coated with the first monoclonal antibody against troponin I and the wells treated with digested casein to prevent unspecific binding of troponin I. The corresponding incubation times for the troponin I measurement were $45 \mathrm{~min}$ and $10 \mathrm{~min}$.

The highest standard of troponin $\mathrm{T}$ was $14.5 \mu \mathrm{g} / \mathrm{l}$, and that of troponin I was $25 \mu \mathrm{g} / \mathrm{l}$. In the daily laboratory practice a few troponin $\mathrm{T}$ values are higher, requiring dilution of the samples; this is often necessary for the measurement of troponin I. The only obvious problem in the standardization of troponin $\mathrm{T}$ was that there is no standard near the critical value of the measurement (between $0.1-0.2 \mu \mathrm{g} / 1$ ). This kind of standard would assist greatly in the accurate measurement of low troponin $\mathrm{T}$ values. The reagents for troponin I supplied to us also contained standards at the critical measurement levels of $0.1-0.2 \mu \mathrm{g} / \mathrm{l}$. However, the standard curve of troponin I was not as steep as that of troponin $\mathrm{T}$.

The variations within-series and between-series were studied using control samples and frozen serum pools. The within-series variations of the methods were acceptable for creatine kinase MB mass, troponin $\mathrm{T}$ and troponin I (tab. 3), being below $10 \%$. The variations between-series were higher and ranged from 4.7 to $8.7 \%$ for creatine kinase $\mathrm{MB}$ mass and troponin $\mathrm{T}$ (tab. 3). The between series variation of troponin $T$ was smaller than in the first modification (14), after addition of a microcomputer with the Genesis ${ }^{\circledR}$ program for the calculation of the results. The between series variation of troponin I was below $10.4 \%$ (tab. 3).

In sera of healthy control persons $(n=95)$ there was very little if any troponin $\mathrm{T}$ and troponin $\mathrm{I}$, while creatine kinase MB mass showed measurable values (2.6 $\pm 1.2 \mu \mathrm{g} / \mathrm{l})$. In sera of healthy persons the mean value of troponin $\mathrm{T}$ was $0.027 \pm 0.025 \mu \mathrm{g} / 1$, the highest value being $0.19 \mu \mathrm{g} / 1$. More than $95 \%$ of all troponin $\mathrm{T}$ values from healthy persons were below $0.1 \mu \mathrm{g} / \mathrm{l}$. By doubling this value, it can be stated that troponin $T$ values in serum greater than $0.2 \mu \mathrm{g} / \mathrm{l}$ should be regarded as abnormal. In comparison, the reference values for troponin I were $0.03 \pm 0.031 \mu \mathrm{g} / 1$, all values were below $0.1 \mu \mathrm{g} / \mathrm{l}$ and the cut-off limit of $0.2 \mu \mathrm{g} / \mathrm{l}$ was used. For creatine kinase MB mass, the upper normal limit was $5.0 \mu \mathrm{g} / 1$ and a cut-off limit of $10 \mu \mathrm{g} / 1$ was selected.

\section{Comparison of the methods in the diagnosis of patients with acute myocardial infarction}

The suitability of the measurements of serum troponin $\mathrm{T}$ and troponin I by microtitre plate ELISA procedures for the diagnosis of acute myocardial infarction was tested using serum samples from 48 patients with verified acute myocardial infarction. The results in figures $1 \mathrm{a}, \mathrm{b}$ and $\mathrm{c}$ show that during the episode, the creatine kinase MB mass, troponin $T$ and troponin I were elevated above the cut-off limits after the onset of the chest pain in all patients with acute myocardial infarction. Troponin $\mathrm{T}$ stayed elevated longer than troponin I. The correlation between serum troponin $\mathrm{T}$ and troponin I values was very high $(0.91)$ in the total material and even higher in the infarct group alone (0.94).

In the control group none of the patients showed any increase in troponin I values in serum (fig. 2c) and only one troponin $T$ value was more than the cut-off limit of $0.2 \mu \mathrm{g} / 1$ (fig. 2b). During the hospitalization period nine control patients showed serum creatine kinase MB mass values between the upper reference limit and the cut-off limit, and two control patients showed values actually over the cut-off limit (fig. 2a), while their troponin $\mathrm{T}$ and troponin I values were completely normal with normal electrocardiographic findings.

In figure 3, the behaviour of creatine kinase MB mass, troponin $\mathrm{T}$ and troponin $\mathrm{I}$ is seen in the sera of $42 \mathrm{pa}-$ tients arriving at the hospital within 12 hours after onset of chest pain. On admission to the hospital it was found

Tab. 3 The within-series and between-series variation of creatine kinase MB mass, troponin T and troponin I methods using low and high serum pools.

\begin{tabular}{lccccc}
\hline & \multicolumn{3}{l}{$\begin{array}{l}\text { Coefficient of variation of creatine kinase } \\
\text { MB mass method }\end{array}$} \\
\cline { 2 - 3 } & \multicolumn{2}{l}{ Within-series } & & \multicolumn{2}{l}{ Between-series } \\
\cline { 2 - 3 } \cline { 5 - 6 } Pool level: & Low & High & & Low & High \\
\hline Mean ( $\mu \mathrm{g} / 1)$ & 4.5 & 15.6 & & 4.6 & 15.2 \\
CV $(\%)$ & 6.7 & 4.3 & & 6.9 & 5.5 \\
No. of analyses & 10 & 10 & & 10 & 10 \\
\hline
\end{tabular}

Coefficient of variation of troponin $\mathrm{T}$ method

\begin{tabular}{|c|c|c|c|c|}
\hline \multirow[b]{2}{*}{ Pool level: } & \multicolumn{2}{|c|}{ Within-series } & \multicolumn{2}{|c|}{ Between-series } \\
\hline & Low & High & Low & High \\
\hline Mean $(\mu \mathrm{g} / 1)$ & 0.24 & 2.28 & 0.23 & 4.35 \\
\hline CV (\%) & 1.5 & 1.9 & 8.7 & 4.7 \\
\hline No. of analyses & 10 & 10 & 10 & 10 \\
\hline
\end{tabular}

Coefficient of variation of troponin I method

\begin{tabular}{lcccccc}
\cline { 6 - 6 } & \multicolumn{2}{l}{ Within-series } & & \multicolumn{2}{c}{ Between-series } \\
Pool level: & Low & High & & Low & High \\
\hline Mean $(\mu \mathrm{g} / 1)$ & 0.94 & 6.43 & & 1.07 & 6.63 \\
CV $(\%)$ & 9.9 & 7.0 & & 10.4 & 7.9 \\
No. of analyses & 10 & 10 & & 10 & 10 \\
\hline
\end{tabular}


that 29 patients had elevated creatine kinase MB mass value in serum, 22 had an elevated troponin $T$ value and 28 an elevated troponin I value. The cumulative increase of creatine kinase MB mass occurred at about the same

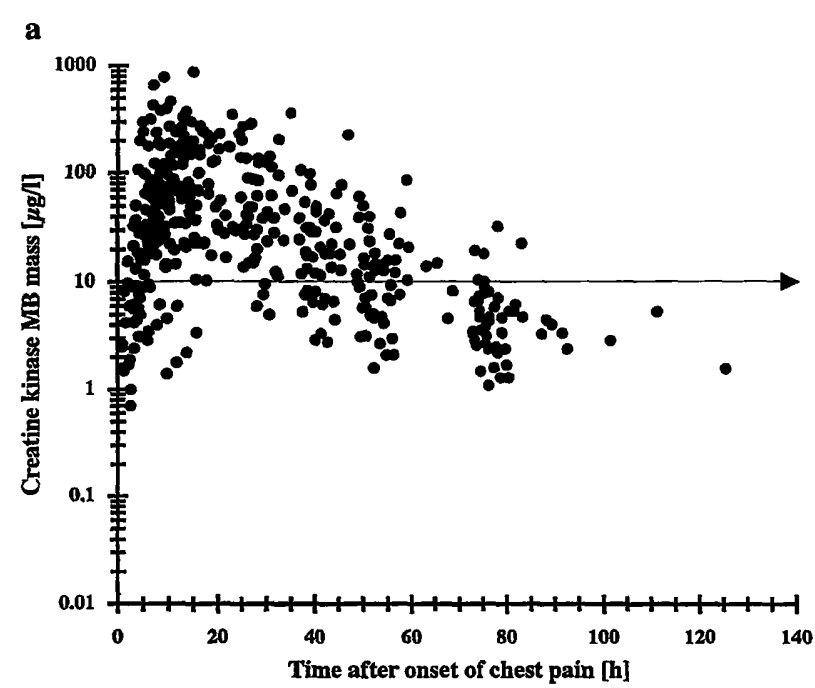

b

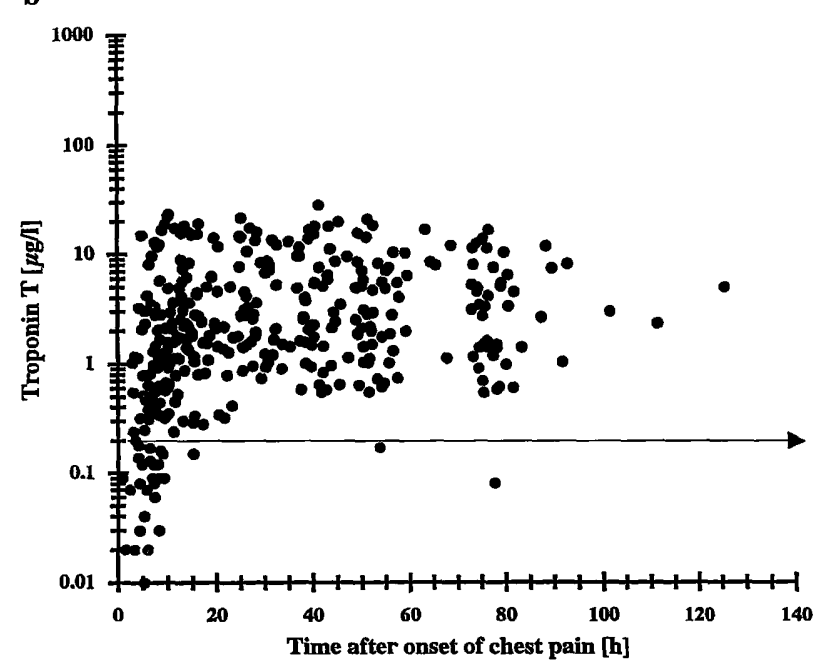

c

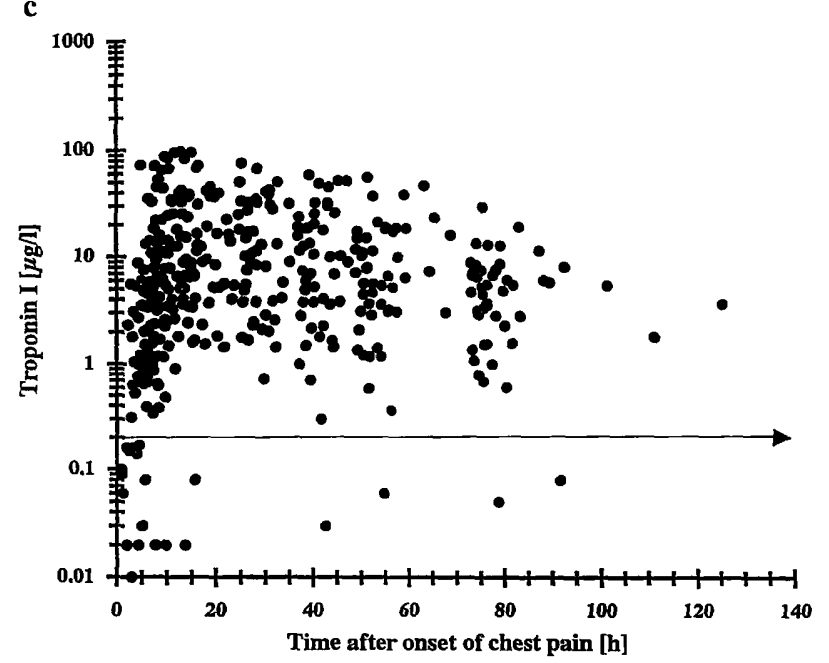

Fig. 1 Typical behaviour of serum creatine kinase MB mass values (a), troponin $T$ values (b) and troponin I values (c) after onset of chest pain in 48 patients with acute myocardial infarction. The lines with the arrow designate the cut-off limits. rate as that of troponin I $(p=0.109)$, while the increase of troponin $T$ was significantly slower $(p=0.043)$ than that of creatine kinase MB mass (fig. 3). The difference in the rates of increase of troponin $T$ and troponin I was

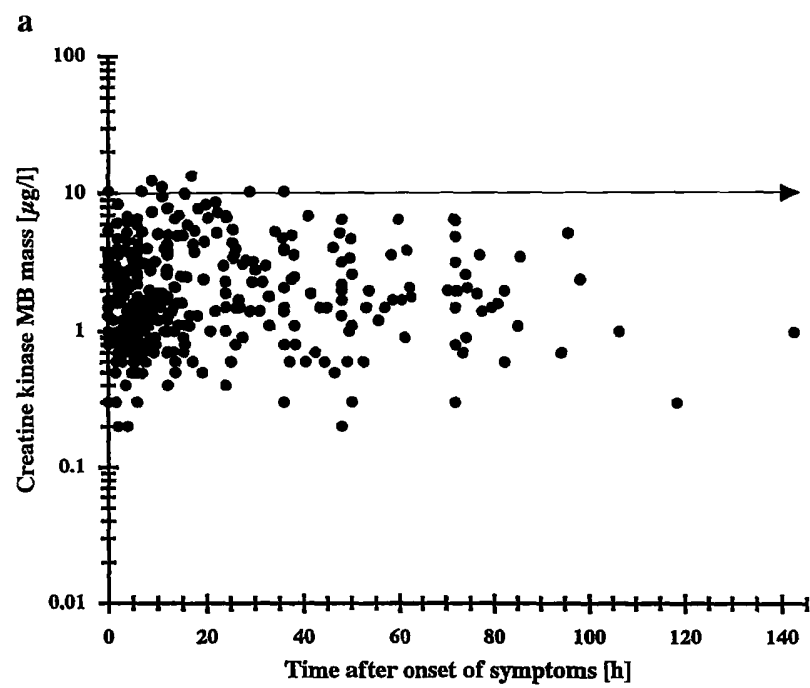

b

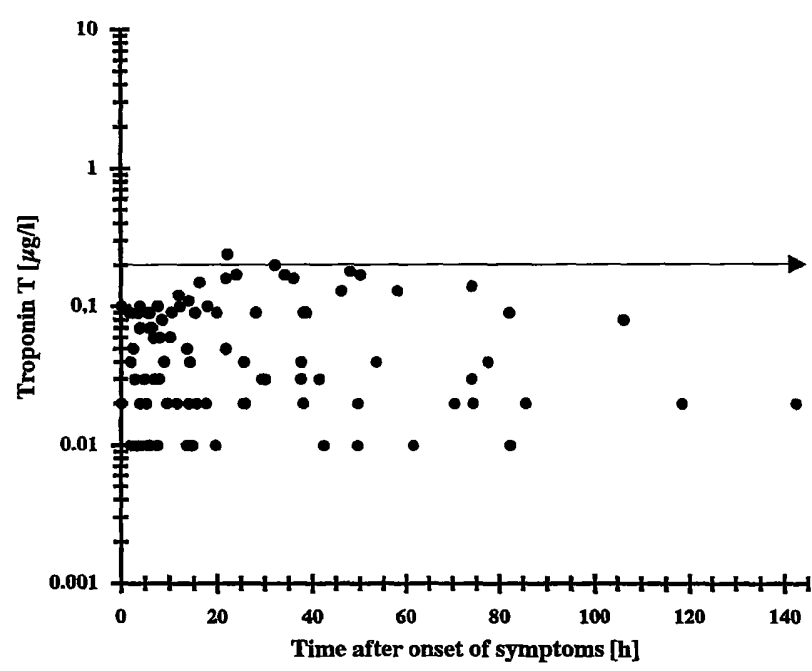

c

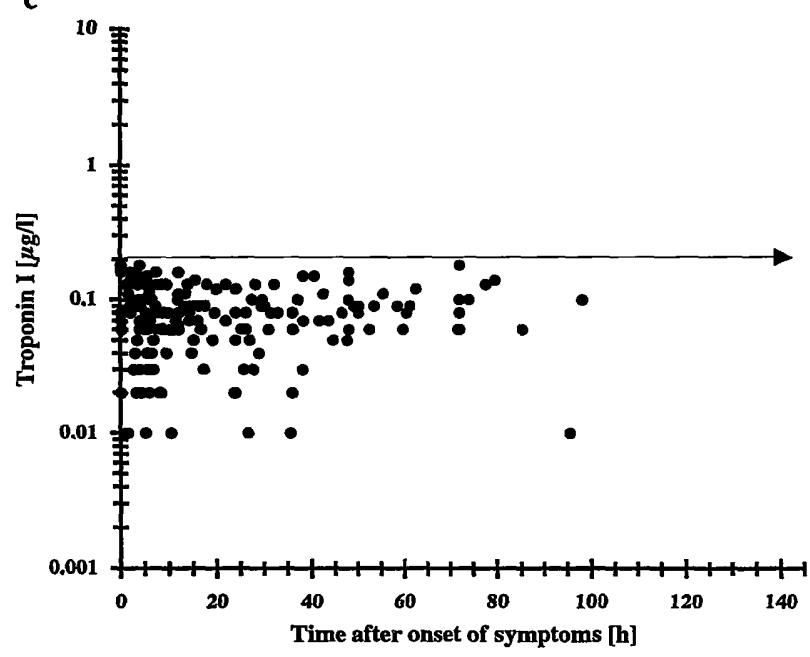

Fig. 2 The behaviour of creatine kinase MB mass (a), troponin T (b) and troponin I (c) values in sera of 60 patients in the control group.

The lines with the arrow designate the cut-off limits. 


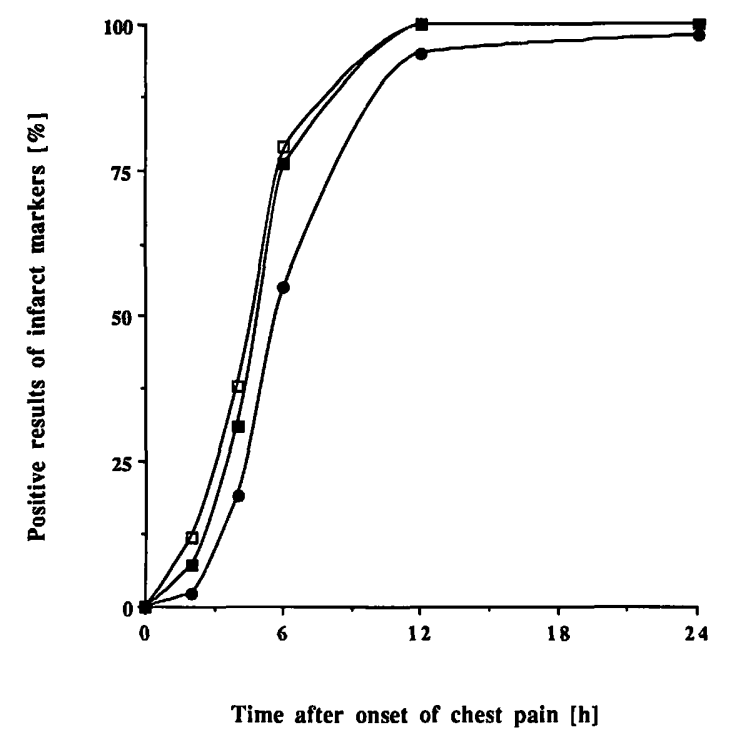

Fig. 3 The changes of creatine kinase MB mass (- $\square-)$, troponin $\mathrm{T}(-\bullet-)$ and troponin I (- -$)$ values in 42 sera from infarct patients arriving at the hospital within $12 \mathrm{~h}$ after the onset of chest pain. The values are expressed as per cent of the patients whose values exceeded the corresponding cut-off limits of $10 \mu \mathrm{g} / \mathrm{l}$ and $0.2 \mu \mathrm{g} / \mathrm{l}$ at different times after onset of chest pain. The significances of the differences between the areas under the curves were: significant between creatine kinase MB mass and troponin $T(p=0.043)$ and troponin $T$ and troponin $I(p=0.043)$ but insignificant between creatine kinase $M B$ mass and troponin $I(p=0.109)$.

also significant $(\mathrm{p}=0.043)$. At $12 \mathrm{~h}$ after admission, all patients with acute myocardial infarction showed creatine kinase MB mass and troponin I values over the corresponding cut-off limits, while troponin $\mathrm{T}$ was below $0.2 \mu \mathrm{g} / 1$ in two patients at $12 \mathrm{~h}$ and in one patient at $24 \mathrm{~h}$, subsequently exceeding the cut-off limit of 0.2 $\mu \mathrm{g} / \mathrm{l}$. At admission and during the hospitalization period, all patients in the control group had troponin I values below $0.2 \mu \mathrm{g} / \mathrm{l}$ and one troponin $\mathrm{T}$ value was just over the cut-off limit $(0.24 \mu \mathrm{g} / \mathrm{l})$, whereas at admission five patients had creatine kinase MB mass values between 5.0 and $10.0 \mu \mathrm{g} / 1$ and two patients had values over the cut-off limit of $10.0 \mu \mathrm{g} / \mathrm{l}$. However, the extent of the increase (value at six hours/value at admission) was highest in the case of troponin $\mathrm{T}$ (quotient 58), being somewhat smaller for troponin I (quotient 32), and smallest for creatine kinase MB mass (quotient 20).

The effect of renal failure was studied by measuring creatinine and troponin values from sera of patients in the control group. The results showed that the troponin $T$ and troponin I values were below the cut-off limit of $0.2 \mu \mathrm{g} / 1$ in sera of all control patients whose creatinine values were over the reference limits and showed concentrations up to $406 \mu \mathrm{mol} / 1$. On the other hand, the highest creatinine value in the group of infarct patients was only $193 \mu \mathrm{mol} / 1$.

\section{Discussion}

Comparison of the values obtained with the microtitre plate immunoassay methods for serum troponin $\mathrm{T}$ and troponin I showed very similar results for diagnosing acute myocardial infarction in patients with acute chest pain. The variation of the methods within-run and between-run were acceptably small for both analyses and correspond quite well to those presented for troponin $\mathrm{T}$ by Hetland et al. (21) and for troponin I by Kuhr et al. (22). The troponin $T$ stayed elevated longer than troponin I, returning to a normal level within two weeks, while troponin I remained elevated for about nine days with a peak at $24 \mathrm{~h}$. The release kinetics of troponin I were similar to those of troponin $\mathrm{T}$, showing both monophasic and biphasic responses depending on reperfusion (6), but troponin $\mathrm{T}$ showed the biphasic response more often than did troponin I.

The troponin I values in sera of the normal population $(\mathrm{n}=95$ ) were below $0.1 \mu \mathrm{g} / 1$ (below the detection limit, defined as the mean of 10 non-specific binding measurements $+3 \mathrm{SD}$ ), and more than $95 \%$ of troponin T values were lower than $0.1 \mu \mathrm{g} / \mathrm{l}$. Both troponin $\mathrm{T}$ and troponin I were not increased in sera of control patients with renal failure whose serum creatinine showed a maximum value of $406 \mu \mathrm{mol} / 1$. This finding differs from that of Bhayana et al. (23) for troponin T but is in accordance with their results for troponin I. From a practical point of view, it seems quite evident that the present methods meet the needs of routine clinical laboratory practice in the diagnosis of acute myocardial infarction, since these proteins were not detected in the serum of patients with non-cardiac diseases $(5,22,24)$.

Katus et al. (10) showed that the lower detection limit for measurement of troponin T is $0.04 \mu \mathrm{g} / 1$ and Gerhardt et al. (25) reported that the upper limit for healthy blood donors for troponin $\mathrm{T}$ in serum is $0.06 \mu \mathrm{g} / \mathrm{l}$. Bodor et al. (11), Kuhr et al. (22), Bertinchant et al. (26) and Mair et al. (27) did not find troponin I in sera of patients without cardiac disease (not detectable). These reports correspond well with the present findings of troponin $T$ and troponin I in the sera of healthy people and patients not suffering from cardiac disease.

Lindahl et al. (28) reported that the determination of troponin $\mathrm{T}$ is a widely applicable method for diagnosing patients acute myocardial infarction, together with myoglobin or creatine kinase MB mass. Adams et al. (29) reported that cardiac troponin $I$ is a sensitive and specific method for the diagnosis of perioperative myocardial infarction and Antman et al. (13) predicted that troponin I is a good marker of acute myocardial damage. The present findings from the infarct and control groups are in agreement, indicating that the specificity of both troponin $\mathrm{T}$ and troponin $\mathrm{I}$ is very high and that the patients with acute myocardial infarction are well diagnosed.

When the behaviour of the cardiac markers creatine kinase MB mass, troponin $T$ and troponin I were com- 
pared with each other, it was found that creatine kinase MB mass and troponin I increased more rapidly in serum of patients with acute myocardial infarction than did troponin T. However, in clinical use there were no major differences between creatine kinase MB mass and troponins in terms of sensitivity and specificity; only the time windows were different. According to the present results, at six hours after admission to the hospital, $95 \%$ of creatine kinase MB mass, $88 \%$ of troponin $\mathrm{T}$ and $93 \%$ of troponin I values were elevated in the infarction group; at 12 hours all creatine kinase MB mass and troponin I values were elevated, while troponin $\mathrm{T}$ was elevated at $12 \mathrm{~h}$ in $95 \%$, at $24 \mathrm{~h}$ in $98 \%$ and at $36 \mathrm{~h}$ in $100 \%$ of patients with myocardial infarction. Thus it seems that creatine kinase MB mass and troponin I values become positive slightly earlier than troponin $\mathrm{T}$ (fig. 3) after onset of acute myocardial infarction, in agreement with the findings of Mair et al. (30). It is quite evident that troponin $I$ in the sera of patients with a myocardial infarction is increased somewhat earlier than troponin $\mathrm{T}$ (fig. 3). It may be that the smaller molecular mass of troponin I compared with that of troponin $T$ accounts for this difference (2). However, the extent of the increase of troponin $\mathrm{T}$ in serum from the initial value was more pronounced for troponin $\mathrm{T}$ than for troponin $\mathrm{I}$ and creatine kinase $\mathrm{MB}$ mass.

Recently, Müller-Bardoff et al. (31) published details of a second generation test for the measurement of troponin $\mathrm{T}$ in serum. With this new method most problems associated with the first generation troponin $T$ method have now been eliminated. But the studies of Bodor et al. (32) on cardiac troponin T composition in normal and regenerating human skeletal muscle showed that the cardiac troponin $\mathrm{T}$ isoform is expressed in certain mus-

\section{References}

1. Staprans I, Takahash H, Russel MP, Watanabe S. Skeletal and cardiac troponins and their components. Biochem J 1972; 72:723-35.

2. Greaser ML, Gergeley J. Purification and properties of the components from troponin. J Biol Chem 1973; 248:2125 - 33 .

3. Parmacek MS, Jeiden JM. Structure, function and regulation of troponin C. Circulation 1991; 84:991-1003.

4. Katus HA, Remppis A, Looser S, Hallermeier K, Scheffold T, Kübler W. Enzyme linked immunoassay of cardiac troponin T for the detection of acute myocardial infarction in patients. $J$ Mol Cell Cardiol 1989; 1:1349-53.

5. Larue C, Colzolari C, Bertinchant J-P, Leclercq F, Grolleau R, $\mathrm{Pau}$ B. Cardiac-specific immunoenzymometric assay of troponin I in the early phase of acute myocardial infarction. Clin Chem 1993; 39:972-9.

6. Gerhardt W, Katus H, Ravkilde J, Hamm C, Jörgensen PJ, Peheim E, et al. S-troponin $T$ in suspected ischemic myocardial injury compared with mass and catalytic concentrations of S-creatine isoenzyme MB. Clin Chem 1991; 37:1405-11.

7. Briggs MM, Schachat F. N-terminal amino acid sequences of three functionally different troponin $\mathrm{T}$ isoforms from rabbit skeletal muscle. J Mol Biol 1989; 206:245-9.

8, Hunkeler NM, Kullman J, Murphy AM. Troponin I isoform expression in human heart. Circ Res 1991; 69:1409-14. cular diseases in adults, and that this is not observed for troponin I $(33,34)$. The very recent findings of Davies et al. (34), for the measurement of troponin I using the antibodies against troponin I from Spectral Co., confirmed that cross-reactivity with skeletal troponin I was absent in concentrations up to $2.0 \mathrm{mg} / \mathrm{l}$. This means that troponin I methods $(5,33,34)$ are very specific for cardiac muscle damage in patients without renal failure, while troponin $\mathrm{T}$ is not $100 \%$ specific for cardiac damage $(24,26,31,32)$.

\section{Conclusions}

The measurement of creatine kinase MB mass and troponin I in sera of patients with acute chest pain seemed to be efficient in revealing acute myocardial infarction, while troponin $\mathrm{T}$ increased significantly more slowly than creatine kinase MB mass and troponin I. Troponin $\mathrm{I}$, according to the present results, provides an earlier diagnosis of myocardial infarction than troponin $\mathrm{T}$. On the other hand, creatine kinase MB mass measurements can be performed on request $24 \mathrm{~h} /$ day (35) in smaller laboratories. The diagnosis of acute myocardial infarction is then confirmed by measuring either troponin $T$ or troponin I from samples taken at 0 and 4-6 hours after admission to the hospital.

\section{Acknowledgements}

The authors thank the personnel of the Departments of the Emergency Care and the Department of Clinical Chemistry of the Kuopio University Hospital, especially technologist Tero Hongisto, for their skilful work during the study. The study was accepted by the Ethical Committee of Kuopio University and Kuopio University Hospital, no. 18/1995.
9. Scheffold T, Remppis A, Kübler W, Katus HA. Only one troponin $T$ isoform is expressed in the failing human heart. Eur Heart J 1991; 12 (Suppl), 215

10. Katus HA, Looser S, Hallermeir K, Remppis A, Scheffold T, Borgya A, et al. Development and in vitro characterization of a new immunoassay for cardiac troponin T. Clin Chem 1992; 38:386-93.

11. Bodor GS, Porter S, Landt Y, Ladenson JH. Development of monoclonal antibodies for an assay of cardiac troponin-I and preliminary results in suspected cases of myocardial infarction. Clin Chem 1992; 38:2203-14.

12. Hamm CW, Katus HA, Ravkilde J, Goldmann BU, Bleifeld W, Gerhardt W. Identification of high-risk patients with unstable angina by troponin $T$ release. Circulation 1992; 82 (Suppl III), 7.

13. Antman EM, Tanasijevic MJ, Thompson B, Schactman M, McCabe $\mathrm{CH}$, Cannon $\mathrm{CP}$, et al. Cardiac-specific troponin I levels to predict the risk of mortality in patients with acute coronary syndromes. New Engl J Med 1996; 335:1342-9.

14. Penttilä I, Hirvonen $K$, Julkunen A, Penttilä $K$, Rantanen $T$. Adaptation of the troponin T ELISA test to a microplate immunoassay reader. Eur J Clin Chem Clin Biochem 1995; 33:59-63. 
15. Penttilä K, Hongisto T, Julkunen A, Penttilä I, Rantanen T. Improvement of the microtiter plate immunoassay method for troponin T in serum. Scand J Clin Lab Invest 1995; 55: Suppl 223:A 610.

16. World Health Organization. Report of the fifth working group on the establishment of ischemic heart disease registers. WHO 1971, Copenhagen.

17. European Committee for Clinical Laboratory Standards. Standards for enzyme determination: creatine kinase, aspartate aminotransferase, alanine aminotransferase, gammaglutamyltransferase. ECCLS Document ISSN 1988; 1011-6265, No. 3-4.

18. Keiding R, Hörder M, Gerhardt W, Pitkänen E, Tenhunen R, Strömme JH, et al. Recommended methods for the determination of four enzymes in blood. Scand J Clin Lab Invest 1974; 33:291-306.

19. Ravkilde J, Hörder M, Gerhardt W, Ljungdahl L, Pettersson T, Tryding N, et al. Diagnostic performance and prognostic value of serum troponin $\mathrm{T}$ in suspected acute myocardial infarction. Scand J Clin Lab Invest 1993; 53:677-85.

20. Norusis M. SPSS/PC+ statistics 4.0 for the IBM PC/XT/AT and PC/2. SPSS Inc., Chicago, USA, 1990.

21. Hetland O, Göransson L, Nilsen DWT. Cardiac troponin T immunoassay on biotin-streptavidine-coated microplates: preliminary performance in acute myocardial infarction. Scand $\mathbf{J}$ Clin Lab Invest 1995; 55:701-13.

22. Kuhr L-P, Baum H, Schweigert R, Hafner G, Prellwitz W, Neumeier D. Evaluation of a rapid quantitative cardiac troponin I immunoassay. Eur J Clin Chem Clin Biochem 1997; 35:399-404.

23. Bhayana V, Gougoulias T, Cohoe S, Henderson AR. Discordance between results for serum troponin $T$ and troponin $I$ in renal disease. Clin Chem 1995; 41:312-7.

24. Collinson PO. To $\mathrm{T}$ or not to $\mathrm{T}$. That is the question. Clin Chem 1997; 43:421-3.

25. Gerhardt W, Katus HA, Ravkilde J, Hamm CW. S-Troponin T as a marker of ischemic myocardial injury. Clin Chem 1992; 38:1194-5.

26. Bertinchant J-P, Larue C, Pernel I, Ledermann B, Fabbro-Peray $P$, Beck L, et al. Release kinetics of serum cardiac troponin I in ischemic myocardial injury. Clin Biochem 1996; 29:587-94.
27. Mair J, Wagner A, Morass B, Fridrich L, Lechleitner P, Dienstl F, et al. Cardiac troponin I relase correlates with myocardial infarction size. Eur J Clin Chem Clin Biochem 1995; 33:869-72.

28. Lindahl B, Venge P, Wallentin L. Early diagnosis and exclusion of acute myocardial infarction using biochemical monitoring. Coronary Heart Dis 1995; 6:321-8.

29. Adams JE, Sicard GA, Allen BT, Bridwell KH, Lenke LG, Davila-Roman VG, et al. Diagnosis of perioperative myocardial infarction with measurement of cardiac troponin I. New Engl J Med 1994; 330:670-4.

30. Mair J, Morandell D, Genser N, Lechleitner P, Dienstl F, Puschendorf B. Equivalent early sensitivities of myoglobin, creatinine kinase MB mass, creatine kinase isoform ratios, and cardiac troponins I and T for acute myocardial infarction. Clin Chem 1995; 41:1266-72.

31. Müller-Bardoff M, Hallenmayer K, Schröder A, Ebert C, Borgya A, Gerhardt W, et al. Improved troponin T ELISA specific for cardiac troponin $T$ isoform: assay development and analytical and clinical validation. Clin Chem 1997; 43:458-66.

32. Bodor G, Survant L, Voss EM, Smith S, Porterfield D, Apple FS. Cardiac troponin T composition in normal and regenerating human skeletal muscle. Clin Chem 1997; 43:476-84.

33. Bodor G, Porterfield D, Voss EM, Smith S, Apple FS. Troponin I is not expressed in fetal and healthy or diseased adult human skeletal muscle tissue. Clin Chem 1995; 41:1710-5.

34. Davies E, Gawad Y, Takahasi M, Shi Q, Lam P, Styba G, et al. Analytical performance and clinical utility of sensitive immunoassay for the determination of human cardiac troponin I. Clin Biochem 1997:In press.

35. Wu AHB, Clive JM. Impact of CK-MB testing policies on hospital length of stay and laboratory costs for patients with myocardial infarction or chest pain. Clin Chem 1997; 43:326-32.

Received May 22/July 10, 1997

Corresponding author: Ilkka Penttilä, Professor, M.D., Ph. D., Department of Clinical Chemistry, Kuopio University Hospital, FIN-70210 Kuopio, Finland

Fax: +358-17-173200, e-mail: ilkka.penttila@uku.fi 